\title{
HYPERREALITY, INTERTEXTUALITY, AND THE STUDY OF LATIN POETRY*
}

\author{
ENRICA SCIARRINO
}

\section{INTRODUCTION}

T

raditionally, the creation of models is a mainstay of the scientific mindset. The idea is to capture the distinctive or essential features of a phenomenon through a simplified or idealized representation of it. Not all models are ontologically the same. They can be descriptive and, therefore, constituted by language, but they can also be non-linguistic and have visual and object-like qualities. Whatever the case, every model raises important questions about its relationship with the phenomenon that it seeks to grasp and the method or procedure by which a model is applied back to the phenomenon. ${ }^{1}$ My aim in this article is to assess the methodological scope of intertextuality in light of recent and less recent reflections on the power of images and the notion of the hyperreal. My goal is to enable an open conversation within and beyond disciplinary and sub-disciplinary boundaries, and to continue to do so despite institutional crises and differences of opinions, experiences, and backgrounds.

As one of Arethusa's readers rightly points out, my contribution "reads more like a suggestive lecture than a carefully argued and

* I should like to thank the many people who patiently contributed to the writing of this rather idiosyncratic piece. Audiences in Berkeley, Vancouver, and Christchurch, Siobhan McElduff, Tesse Stek, Terry Austrin, Tom Habinek, Chris Jones, Lily Nabi, Julia Shirar, Simon Ogden, and many others. To Giulia, for her courage and her freshness. Translations are mine unless noted.

1 A good map of issues relating to scientific models can be found in the Stanford Encyclopedia of Philosophy at http://plato.stanford.edu/entries/models-science/ 
documented journal article." It does indeed, and I left it so intentionally. I was collecting ideas and texts for this little project when, on the early morning of September 4, 2010, a 7.1 earthquake hit Christchurch, the city in which I live and work. On that occasion, the city suffered serious damage (including the library), but fortunately there were no fatalities. On February 22, 2011, on the same day the library finally reopened and the second day of the new academic year, another major earthquake hit the city. This time 185 people died, and it is unclear how many were injured. A week later, we resumed teaching in tents set up on campus and carried on business "as usual" throughout the whole year, without libraries to go to, and offering support as best we could to the students who did not flee the city. This article has developed in that environment. Most of the considerations that it contains arose during precious conversations with friends and colleagues, while browsing notes scattered in notebooks and electronic documents, and through Google searches. Accordingly, this is a theoretical reflection, but it is also an experiment in what it means to pursue humanistic work in crisis situations - and to keep doing so in spite of major disruptions and minimal resources.

\section{DISCOURSE AND RELATED MATTERS}

In the last decades, the term "discourse" has become increasingly common in a variety of disciplines, so much so that it is invariably left undefined as if its meaning were self-explanatory. In the analysis of literary texts, "discourse" invokes the work of a group of French philosophers of the late 60s. Michel Foucault is one of them, and in his Archaeology of Knowledge, he defines discourse as follows (1972.80):

Instead of gradually reducing the rather fluctuating meaning of the word "discourse," I believe that I have in fact added to its meanings: treating it sometimes as the general domain of all statements, sometimes as an individualizable group of statements, and sometimes as a regulated practice that accounts for a number of statements.

In the first definition, discourse is an entity made out of sequences of signs organized in the form of enouncements (enoncés) or statements; in the second, discourse is the combination of statements that characterize large bodies of knowledge: something comparable to the disciplines 
or areas of human endeavor. In the third, it blends with practice and the cumulative norms that determine the production of specific statements.

Foucault's definition of discourse draws heavily on Ferdinand de Saussure's understanding of the linguistic sign and the enormous success that this understanding has encountered among theorists. In his Course in General Linguistics (1916, French ed.), de Saussure distinguished between parole and langue. Parole refers to the realm of individual moments of language use - of particular "utterances" or "messages," whether spoken or written - and langue to the system or code of the language (le code de la langue) or, to put it in de Saussure's words, to "the social product of the faculty of speech and a collection of necessary conventions that have been adopted by a social body to permit individuals to exercise that faculty" (de Saussure 1959.9). According to de Saussure, the linguistic sign emerges from a dyadic relation between parole and langue, consisting of a form or a sound-image, the signifier (signifiant) — which belongs to the area of parole — and its concept, the signified (signifié)—which belongs to the area of langue. De Saussure saw this relation as being arbitrary, by which he meant motivated by social conventions.

What makes the term discourse appealing, then, is the feeling of both groundlessness and groundedness that it generates: on the one hand, it destabilizes the unity of individual signs and the relationship between signifier (parole) and signified (langue); on the other hand, it privileges language as a basis of analysis and circumscribes any experience of the world (including practice) within the limits of language itself. What follows is that any understanding of "text" based on discourse is linguistically constructed, and so is any embodied experience related to it. In this respect, it is important to keep in mind that discourse is less a methodology than a model. As a model, it is an expression of a long-existing tradition that goes back to the concept of logos and is a manifestation of a very specific moment in intellectual history. In his assessment of Warren Neidich's work, Norman Bryson offers an acute representation of what I am trying to say here (2003.2-3; emphasis in original):

The effort of the "linguistic turn" in philosophy lies in transforming questions asked of Being into questions asked of language. In the later philosophy of Wittgenstein, for example, "the limits of my language are the limits of my world." Which is to say that the language with which consciousness thinks does not picture or represent the 
world directly; rather, language itself is the primary reality, and attempts to establish the existence of a world outside the linguistic are invalid or meaningless. What holds the world together, then, is the coherence of the rules by which language operates, the "language games" that particular communities bring into being in their construction of a shared, coherent reality. Similarly in Derrida, nothing stands outside the signifier in the position of signified: a word does not derive its meaning from outside the system of language, for instance from an intention or thought that language reflects or reiterates, or from a referent-a thing in the world - that language names. Rather, meaning is the effect of movement from one signifier to the next, in a circulation that is "groundless" in that it rests (as in Wittgenstein) on nothing outside the circuit of language itself. And again in Lacan, the Symbolic order is a system that does not rest on a prior reality but rather marks a fundamental break from reality, in which the signifier is hollowed out by the absence of the thing it names: the Symbolic order exists in opposition to the Real, and can never adequately represent or embody a Real that is understood to lie outside all symbolic conventions . . . Feeling, emotion, intuition, sensation - the creatural life of the body and of embodied experience - tend to fall away, their place taken by an essentially clerical outlook that centers on the written text. The signifier rules over a set of terms whose functions are primarily textual in scope: the analysis of ordinary language (Wittgenstein); of the circulation of meaning within the literary text (deconstructive criticism); of the disruptions of the symbolic order that indicate the advent of unconscious fear and desire in the analysis of speech or in the discourse of the work of art (psychoanalysis). While the family of terms that owe their allegiance to the signifier-text, discourse, code, meaning - is brilliantly adept at dealing with questions of signification, it encounters a notable limit when the area that it seeks to understand exceeds the sphere of textual meaning. Though semiotics is often at pains to point out that the signifier belongs to the sensory order, 
it is difficult to modulate the term so as to include the full range of sensuous and emotional experience, the affective, the physical, and the kinesthetic.

In the last thirty years or so, discourse and de Saussure's conceptualization of the sign have greatly affected the development of intertextuality as the primary model used in the study of Latin literature in general and Latin poetry in particular. Born as a reaction to the monopoly of New Criticism in the Anglo-(North)American world and as a redress to the crisis of traditional historicism in Italy, intertextuality assigned primacy to the reader as meaning-making agent and, by calling into question the unity of a text, located meaning in the relationship of a text with prior texts and in the generic codes that these texts used. Discourse opened up the possibility of exploring textual relations through language and the use of generic codes as regular and systematic meaning-making rules. In hindsight, the outcome has been twofold: Latinists have been able to rework philological methods in order to define literary genres in an interrelated manner and, on this basis, to construct literary histories. And they created normative reading practices that have drawn force and authority from the exclusion of the sensorial and the embodied.

In the late nineties, a number of concerns about intertextuality as a model began to arise, and rightly so (Barchiesi 1997). Exemplary in this respect is Stephen Hinds' Allusion and Intertext: Dynamics of Appropriation in Roman Poetry, published in 1998. In his book, Hinds reflects on how to distinguish between allusion and the accidental confluence of words or commonplaces. He also raises the issue of how to treat authorial intention, stressing that from the point of view of interpreters, the alluding author, however conjectural, is still instrumental, still "good to think with" (Hinds 1998.119). Turning next to the role of reading, Hinds uses as a case-study the archaic Roman poets (Ennius in particular) and points out the extent to which readings of them in antiquity continue to inform our literary histories. Finally, he focuses on the status of the text under examination in relation to the alluded texts, asking what hierarchies structure their relationship - in other words, which of them constitutes the master-text.

In 2001, Lowell Edmunds published Intertextuality and the Reading of Roman Poetry as a response to Hinds' reflections. In discussing the nature of allusions, Edmunds claims that they should be regarded as "pleasing or intriguing, often unordinary, uses of language that convey or portend some meaning valuable to the reader" (2001.xiii). Building upon 
that, Edmunds dismisses the possibility that a poem may actually perform something in the world and proposes that it is "the poet's adoption of a persona, his speaking in a fictional voice, that gives a poem its special status outside the ordinary uses of language" (2001.37). As for the issue of authorial intention, Edmunds argues that the very difficulty of introducing information about ancient authors from outside the poems downgrades intentionality to nothing more than "the scholar's rhetorical add-on at the conclusion of an interpretation” (2001.xii). To Hinds' reconstruction of how the early Roman poets were assigned archaic status by later readers and to his wondering about what vantage point we should be adopting, Edmunds reacts by characterizing this sort of exercise as purposeless. Edmunds also makes the claim that in the late first century B.C.E., a new type of reading began to develop, a type of reading centered on a cognitive and aesthetic experience similar to our own (2001.31, 108-09). Finally, Edmunds defines the interpretation of Roman poetry as an aesthetically based reading practice that finds validity in what he calls the "Latin sub-community" and the "conventions of its discourse" (2001.168-69).

Consciously or not, Edmunds endorses the study of poetic allusions to the extent that he transforms intertextuality from one model among many into the only acceptable one. The position that he adopts is inevitably accompanied by the assumption that intertextual analyses of late republican and post-republican poetry are the very discourses and conventions that structure the Latin "sub-community." Also, by claiming that there is nothing there beyond texts and readers, Edmunds invalidates any attempt to understand the agency of the author in the production of texts, the subjectivities embedded in the text, and the socio-historical circumstances that guided the author's choices. Such a rigid position was understandable thirty years or so ago, when Latinists needed to justify the secondariness of Latin poetry vis-à-vis their Greek counterparts and counter the positivistic notion of texts "as transparent windows looking onto an unproblematic external reality."2 As Dale Wang recently put it (2013.7-8), the text is the author and the author is the text: the author's history is in the text. Wang's reflection fits with what is already acknowledged in words when we call the surviving texts attributed to a particular author a corpus. ${ }^{3}$ After all, the

2 The citation here is from the introduction to Fowler's unpublished manuscript, Unrolling the Text.

3 For an acknowledgement of the relationship between a literary corpus and the body of the author, see Gowers 2009.17-37. 
text is the way in which the author makes himself present in the world, with his experience of the world driving the way he goes about it. Accordingly, Edmunds' interpretation of Roman poetry as an aesthetically pleasant reading practice is valid only in part, as his understanding of aesthetics as an exclusively intellectual reading exercise disregards the sensory dimension of aesthetics itself and rules out differences in sensibilities, be they related to the contextual circumstances of the author or the reader.

The same holds true for those Latinists who, like Charles Martindale (1993 and 2005), defend the superior hermeneutical value of "literature" by invoking the return of aesthetics in the form of a judgment of taste based on a "disinterested" appreciation of beauty. These views draw on very specific philosophical interventions (Kant and the British empiricists). The contextual and historical ramifications of these interventions cannot be emphasized enough; however, when reworked into inflexible interpretative frameworks, they enable "a narcissistic suppression of the 'other'/author in favor of a multiplication of the 'self'/reader" - as one of Arethusa's readers puts it - that rests on a series of acts of separation: the separation of the redeemed from the damned, of the purified from the corrupt and the degraded, and, I would add, of the whole from the fragmentary, and of the mind from the body. ${ }^{4}$ In the study of Latin literature, these views have reinforced existing binaries (poetry vs. prose, written vs. oral, form vs. history) and have hampered divergent approaches and collaborative efforts. ${ }^{5}$

Questions about the sensory and the sensual should not be dismissed, nor should they be seen as oppositional to discourse, the aesthetic, or the intellectual. Language — whether written or not, spoken or not-has a performative dimension to it that is based on its materiality. If in the realm of philosophy, thinkers like J. L. Austin and Judith Butler (to cite just the most influential) speculate about how to do things with words and how words do things, linguists working in the area of phonetics and phonology teach us that language is material and that it is through its materiality that human communication takes place. ${ }^{6}$ Perhaps it would be a good idea to start by admitting that (1) whenever we use language we express in very material terms our positioning in the unfathomable networks that

4 For the language used here, see Mitchell 2005.147.

5 To have a sense of the dynamics of the discussion, see Habinek 1998 and 2005a, Goldberg 2005, Feeney and Katz 2006, and Sciarrino 2011.1-37.

6 Austin [1962] 1975 and Butler 1993, 1997. 
make up communities or sub-communities, and that (2) we are always interested even when all we want is to appreciate beauty in its pure form.

The world is not made up only of language and linguistic signs but of images as well. How we think about images and how we think about how they affect each and every one of us makes a difference. Images impose themselves through objects; texts are objects too, and the words that they contain affect us in a less immediate way than images, perhaps, but with similar results. Words in texts - regardless of whether they are silently read or listened to - and images embedded in art objects impress themselves upon our minds. ${ }^{7}$ We may call these mental impressions "imaginary"; using such a term does not make them any less a product of physical processes in the brain. ${ }^{8}$ In what follows, I draw on some reflections on the power of images in order to establish the basis for a fresh view of the allures of intertextuality and Roman ways of perceiving texts. What I am entertaining here is a cross-modal analogy between images and texts in order to illuminate what strictly textual/linguistic/discursive analyses do not allow us to appreciate in full.

\section{THE HYPERREAL}

In a lecture presented at the Institute for Advanced Study in Princeton in 2010, Horst Bredekamp discussed the power of images by taking as a point of departure Leonardo da Vinci's ideas about painting. ${ }^{9}$ We know about these ideas because Leonardo jotted them down. These writings were gathered together after his death in what is now known as Il Trattato della pittura. Here Leonardo speaks on behalf of painters and in opposition to poets. At one point he asserts (Trattato della pittura 9):

Il pittore è padrone di tutte le cose che possono cadere in pensiero all'uomo, perciocché s'egli ha desiderio di vedere bellezze che lo innamorino, egli è signore di generarle e

7 Classicists are well aware that, in the ancient world, images and objects were everywhere, and have long been exploring their relationship with texts. The bibliography is massive; I cite here only three representative studies: P. Zanker 1990 (for Augustan Rome), Steiner 2002 (for archaic and classical Greece), and G. Zanker 2004 (for the Hellenistic period). Bredekamp also cites the very influential Svenbro 1993, whose publication sparked a huge debate about orality and textuality that continues to this day.

8 For a variety of interventions from diverse perspectives, see Stafford 2011.

9 Bredekamp 2010. What follows refers to and expands on his video-recorded lecture. 
se vuol vedere cose mostruose che spaventino, o che sieno buffonesche e risibili, o veramente compassionevoli, ei n'è signore e creatore.

The painter is master of all things that can fall into the mind of man; insofar as he (man/painter) desires to see beauties that enamor him, he is the god who generates them; and if he wants to see monstrous things that trigger fear or that are clownish or laughable or truly pityinducing, he is lord and creator of them.

The power of the painter is here assimilated to that of God in his ability to create a reality that he or other men (or both) desire. The use of pronouns in this passage produces a slight referential confusion, and this confusion points to the merging of the "I" of the painter and the "I" of mankind collectively understood (uomo). The merging, happening at the level of language, is also a merging of different realities and subjectivities; in this merging, the painting is an object figured as a manifestation of individual and collective desires and the painter as the agent who makes these desires not only materially and spatially present but alive as well.

In his Princeton lecture, Bredekamp cites another extract from Leonardo's writings in order to reflect on the liveliness of images: "non iscoprire se libertà t'è cara / ch'l volto mio è carcere d'amore" ("Do not uncover if freedom is dear to you, because my face is a prison of love"). ${ }^{10}$ It would appear that these lines were meant to serve as a legend appended to a portrait; if so, through them, Leonardo expresses the creative power of the painter by endowing the art object with speech - a speech in which the object articulates the captivating qualities of the painted image. In the same lecture, Bredekamp notes that Leonardo was aware "that the world is filled with forces of such violence that they cannot be comprehended entirely by the senses and that require the help of art. Art is able to generate an effective surplus that does not imitate reality but produces a superreality." To put it in Leonardo's terms, this super-reality is what binds the beholder in a state of amorous, if not erotic, imprisonment and expresses what I would call the "sentiment of love."

10 Leonardo, South Kensington Museum 3, f. 85 recto $=$ Forster III, f. 10 verso. I have the impression that Bredekamp in his lecture does not cite the second line; this is not crucial to his argument, but it is for mine. 
Generally speaking (and paraphrasing what we find in Wikipedia), I here use "sentiment" much the way people working in the field of opinion mining do when they attempt to identify and extract subjective information in source materials. ${ }^{11}$ In that field, sentiment amounts to the attitude and inclination of a speaker, writer, or artist with respect to an object and the overall "contextual polarity" or, better perhaps, "magnetic attraction" towards that object. Attitude and inclination include his or her judgment or evaluation, their affective state when speaking, writing, or making an object, and the intended communication (that is to say, the emotional effects the artist, author, or speaker wishes to have on the listener, reader, or beholder). In sentiment analysis, the task is to classify that magnetism. Clearly, the same sort of analysis should encompass the listener, the reader, or the beholder as they also are affected by "magnetic attraction." Put in purely linguistic terms, magnetism belongs to the realm of langue, but in order to get to that, the analysis must necessarily start from experiential manifestations in the realm of parole. Sentiment analysts start from and go back to the realm of emotions by classifying, for instance, emotional states such as "angry," "sad," "happy"; afterwards, they reconstitute the underlying sentiment and the inclination of the subject at some particular moments. This method can help us define better Bredekamp's idea of super-reality.

In a dialogue with Barbara Stafford published by Tate etc., Bredekamp defines super-reality as an intensified form of reality and names it "hyperreality." Moreover, he suggests that hyperreality has "a paradoxical existence": 12 on the one hand, you have compression or contraction, on the other hand, you have revelation by magnification. In other words, the perceptual reality is compressed into the confines of the art object; in turn, the art object reveals that reality and magnifies it within the limits of the art object itself. In a way, the art object comes to encompass the whole world in a compressed manner. For Bredekamp, hyperrealism is very effective primarily because it possesses a "phatic" dimension. Roman Jakobson introduced the term "phatic" to refer to any linguistic expression that is meant to elicit an immediate and focused response. Phatic expressions include: "Hello?" "Hi there!" "What's up?" and the like (Jakobson 1970.217). Redeployed in the study of images, Paul Virilio defines "phatic image" in his The Vision Machine in the following way (1994.14): "The

$11 \mathrm{http} / /$ en.wikipedia.org/wiki/Sentiment_analysis

12 Here I am freely paraphrasing and adding to Bredekamp 2006. 
phatic image - a targeted image that forces you to look and holds your attention - is not a pure product of photographic and cinematic focusing. More importantly it is the result of an ever-brighter illumination, of the intensity of its definition, singling out only specific areas, the context mostly disappearing into a blur."

Thus compression and magnification in visual art produce hyperreality and affect the beholders by grabbing their attention at the expense of everything else that occupies the perceptive space available to them. But there is more. For Bredekamp, hyperrealism also meets and captures the human desire for transcendence, that is, the aspiration to liberate the self from its material existence. Inevitably, this aspiration leads to a return (in)to the material and the body of all involved. Whether this return is to be understood as a fall from grace depends on the value that we attribute to the material and the body, and how much we cherish the relationship of both the material and the body with the mind. Moreover, as Barbara Stafford notes during the same conversation (2006), "Hyperreality is an instrument of activity that goes beyond pure visualization. With hyperreality there is always a question of identity ... [for] it perpetually deflects the question of where is the real in its overproduction of too many or too much, so that one is unable to make a decision."

In my view, there is no decision to be made, for it would appear that reality, hyperreality, and unreality stand in a relationship of interacting continuity. We may conceive reality as sitting somewhere in between the hyperreal and the unreal. We could perhaps represent it in terms of degrees of belonging to dualistic sets like truth and fiction, objective and subjective, material and immaterial, body and mind, and so on. Whatever the case, the degree of belonging to any or all of these sets would depend on the pattern recognitions of both the creator of the object and its beholder. How these patterns are shaped and how, in turn, their shape affects classifications and actions are matters that lie in the hands of humanists. What I would like to do next, then, is think more directly about Latin poetry and intertextuality in light of the notion of hyperreal.

\section{HYPERREAL AND TEXTS}

Whatever falls within a text can be defined as hyperreal to the extent that it is both a compression and a magnification of the world that is contained within the limits of the written object and achieved by means of words produced by an author. This is so regardless of what the writing material is or 
what form the writing takes. This is not to say that these material aspects do not matter; as I discuss later, they carry a great deal of importance. ${ }^{13}$ At another level, a text materially conceived is a microcosm of its own that, as intertextuality has taught us, is linked to other texts. Intertextualists tend to be engrossed especially with the thematic and lexicological features of a text and on how they relate to previous or contemporary texts within the literary archive. I suggest that attention be paid to the phatic qualities that texts contain and how these qualities grab and capture the attention of the reader/viewer. I would also insist that texts are very material, and this materiality manifests itself most clearly (for us) in formalities like figures of sound and metrical structures.

Needless to say, attention to these formalities is routine for every classicist working on poetry - and prose to a lesser degree. If we think of these matters in strictly material terms, a whole new world of allusions opens up before our eyes. These allusions exceed the limits of the text and the textual tradition, and come to encompass the author's own magnetic attraction towards his text. Put in terms of discourse, they spill into langue, into signification. This is culturally and contextually determined and not entirely intellectual, as signification also includes, to paraphrase Bryson 2003, a full range of sensuous and emotional experiences: the affective, the physical, and the kinesthetic. Compressed and magnified in the text, and mediated through the choice and arrangement of linguistic signs, these experiences exude that "sentiment of love" that-as Leonardo recognizes in relationship to painting-imprisons the reader and the author in the text at any given time. Accordingly, we should be mindful of the phatic dimension that texts contain and how these grab and capture the reader's attention. Roman poets and others were well aware of this power. I will exemplify my point by turning to the first lines of Horace's Ars Poetica and then to a few Catonian fragments:

Humano capiti ceruicem pictor equinam iungere si uelit et uarias inducere plumas undique collatis membris, ut turpiter atrum desinat in piscem mulier formosa superne, spectatum admissi, risum teneatis, amici?

13 Winsbury 2009.15-45 is an introduction to the issue of writing materials in the Roman world. References are scattered, but on wax tablets, see the excellent book by Meyer 2004. 
Credite, Pisones, isti tabulae fore librum persimilem, cuius, uelut aegri somnia, uanae fingentur species, ut nec pes nec caput uni reddatur formae. «Pictoribus atque poetis quidlibet audendi semper fuit aequa potestas.»

Scimus, et hanc ueniam petimusque damusque uicissim.

If a painter should like to place a human head

On a horse's neck, with a melding of limbs covered

Everywhere with multi-colored plumage, so

That what was a lovely woman, at the top,

May end repulsively in the tail of a black fish:

Asked to a viewing, could you stifle laughter, my friends?

Believe me, a book would be similar to such a picture,

Dear Pisones, if its hollow appearances were figured like the dreams

Of a sick person, that neither head nor foot could be reduced

To a unified form. "But painters and poets

Have always shared an equal power of daring anything."

We know it, and we claim that license, and grant it in turn.

(trans. A. S. Kline, slightly modified)

In this passage, Horace displays the same keen awareness of the power of poets and painters that Leonardo manifests later. Poets and painters are assimilated as equal stakeholders and shareholders of the power (potestas in line 10) of creating whatever reality they choose, but only to a point. In fact, Horace circumscribes their power within the limits of the Aristotelian model of formal unity (una forma, lines 8-9). As a poet, Horace makes his potestas present through the text that we read and expresses his allegiance to formal unity by constraining his words within the bounds of the hexameter and by offering a version of reality that has a beginning, a middle, and an end. Horace here endows his text with liveliness by figuring an interaction between his poetic "I" and the "you" of the Pisones (his addressees). The reality created by the interaction is not fictional, imaginary, or unreal; it is, first of all, hyperreal insofar as it compresses 
the world to just this interaction and magnifies this interaction to the exclusion of everything else.

Moreover, in this passage, the sentence "Pictoribus atque poetis / quidlibet audendi semper fuit aequa potestas" (lines 9-10) does the job of phatically capturing the attention of readers and their desire to transcend the "here and now" (see semper, line 10). Accordingly, Horace alerts us to the fact that poetry (like painting) does not allow readers to stand outside the text and freely eavesdrop on what goes on inside the confines of the text. Rather, the hyperreality of the text becomes a reality that allures and traps everyone involved; in our case, these include the poetic ego, the figured Pisones, and the readers. As readers, then, we end up being blinded by the illusionary trick that Horace plays: by dissecting the allusive texture of his poem, we participate in the poet's game of flaunting mastery over the Graeco-Roman tradition. By enjoying the pleasure of the text, we fall into a state of admiration and awe for Horace's poetic skills.

Intertextuality thrives on the hyperreal, and the poetic game empowers it. From a scholarly point of view, intertextuality is at its best in its attempt to reconstruct the network of associations that any given poetic text establishes with other texts and textual traditions. The reconstruction of this network enables us to identify with a degree of certainty the kind of cultural materials that were available at the time of a text's production. What makes intertextuality problematic is that it encloses the materiality of history and the body within the bounds of poetic allusions and seamless literary genealogies. As a result, we fall for an erotic game that is hard to give up and lose interest in the numerous rifts and accommodations that informed the history of Latin poetry and its embodied and material nature.

\section{THE MATERIALITY OF POETRY}

The beginnings of Latin poetry are associated in the sources with the translation practices of a small group of professional immigrants who moved to Rome in the late third and early second centuries B.C.E. Intertextuality has tended to look at early poetry as some sort of literary bridge between Greece and Rome or as an unproblematic source of poetic allusions more fully developed by later (and more mature) authors. From the same period, however, other texts have survived; among these are the writings attributed to Cato the Censor.

When we apply to Cato's writings the criteria that we use for the study of Latin poetry, we cannot avoid feeling confused. On the one 
hand, these writings bear features that defy our ability to straightforwardly identify allusions to Greek precedents; on the other hand, the only texts in Latin that we have from more or less the same period are scraps of laws, ritual regulations, inscriptions in tombs and temples, and the like. Later authors represent the formalities that characterize these texts as shapelessly fluid and primitive, and oppose them to the sophisticated "shapeliness" of metrical norms and Greek models. These shapeless cultural expressions are generally associated with the carmen.

Thomas Habinek introduced the use of the term carmen as a synonym of song in order to systematize the various forms of ritualized speech that characterize the Latin literary corpus and undo the opposition between oral and written (Habinek 2005a and b). In a recent work on the formation of Latin prose, I suggest that in the late third and early second centuries B.C.E., the carmen was associated with pre-poetic and non-poetic cultural expressions and was characterized by very distinctive strategies. These strategies are not only verbal but bodily as well. At a verbal level, they are normally bracketed under the rubric "carmen-style" and include juxtaposing longer and shorter compositional segments, manipulating figures of sound, and stringing together two or three words..$^{14}$ At the level of the body, they typify activities that were perceived as vital for connecting the polity and its people to the cosmic whole and as empowering ploys for making this connection present for the cognitive endorsement of all. One of these activities involved the production of tabulae.

In her recent work on tabulae (2004), Elizabeth Meyer argues that these objects were embedded in actions undertaken on behalf of the legitimate and desired socio-cosmological order. Not surprisingly, these tabulae tend to bear compositions presenting carmen-like features. In turn, the fact that the carmen-style also characterizes compositions fashioned outside the sphere of legitimate power (that is, in the sphere of magic, generally speaking) and that this outside sphere was tightly policed give us clues about the performative potency that any invocation of the carmen (embodied or textual) was believed to possess. ${ }^{15}$

14 For definitions of the carmen-style, see Norden 1986.172-73, Palmer 1961.346-57, Timpanaro 1988.257-61, von Albrecht 1989.9-20, and Courtney 1999.1-11.

15 On this specific point, see Meyer 2004.103-07. In his recent thesis, Maxime Pierre 2008 argues that a carmen is an utterance that carries its authority within itself, i.e., it has an authority that is not derived from the social authority of its author. The first sign of carmen policing is to be found in the Twelve Tables (7.3). 
In the Preface to the Origines, Cato invokes the carmen in at least two of the remaining fragments. The first reads as follows: ${ }^{16}$

grauissimus auctor in Originibus dixit Cato "morem apud maiores hunc epularum fuisse, ut deinceps, qui accubarent, canerent ad tibiam clarorum uirorum laudes atque uirtutes."

That most sober author Cato said in the Origines that there was the following custom during banquets among the ancestors: those who reclined would sing in turn to the sound of the pipe the praises and the manly deeds of famous men.

This fragment features a scene in which a select group of people is gathered at a convivium. While reclining, these people sing and praise the manly deeds of clari viri in turn. Here the phrase apud maiores and the use of the imperfect are phatically meant to command attention to two claims: that individuals acquire perceptual distinctiveness or claritas on the basis of their achievements and that objectified in song, these achievements serve as behavioral standards for the reproduction of the group and of social hierarchies at the same time. ${ }^{17}$ In another fragment belonging to the Preface, Cato adds:

Etenim M. Catonis illud quod in principio scripsit Originum suarum, semper magnificum et praeclarum putavi, "clarorum hominum atque magnorum non minus otii quam negotii rationem exstare oportet." 18

Indeed, I always deemed magnificent and outstanding what Cato wrote at the beginning of his Origines, that no less

16 Cicero Tusc. Disp. 4.3 = Cato Orig. 1.4 C\&Sbl.

17 For a discussion of claritas as perceptual distinctiveness, either auditory or visual, and its difference from gloria, see Habinek 2000.269-70. For an account of Cicero's understanding of gloria, see Mazzoli 2004.

18 Cicero pro Planc. 66 = Cato Orig. $1.2 \mathrm{C} \&$ Sbl. Imitated with variations by Cicero ad Att. 5.20.9, Symmachus Epist. 1.1.2, Ennodius Carm. 1.9.3, and Columella RR 2.21.1. 
an account of leisure time than of work time of famous and great men ought to remain.

Here Cato invokes the financial accounts (rationes) that male Roman citizens wrote on tabulae and presented to the censor. During the taking of the census, the rationes embodied the ability of male Roman citizens to manage their households and constituted the means by which these men were accorded responsibilities and privileges. ${ }^{19}$ In the Origines, the invocation of these rationes serves to define a specific type of text. Produced by eminent men, these texts are supposed to objectify in words their social performances and fulfill the same socially reproductive function attributed to the singing of convivial songs.

From Cato's writings, subjectivity emerges as shaped by different experiences of the world and by a keen sense of the body's connectedness with a socio-cosmological order in which things have meaning in themselves. This bodily connectedness or "worldly presence" (if you like) is not achieved through the creation of texts bearing allusions to a previous textual tradition made up of allusions; rather, it is based on a very practical adherence to a socio-cosmological order materially perceived and materially expressed..$^{20}$ In this world, texts are material objects, monumenta, that bring to mind and make discernible a person's ability to live up to the potential associated with his place in the world. The censorial ceremony, with the presentation of written accounts (rationes) by the pater familias to the censor, on one side, and the censor's production of a citizen list that systematizes citizens according to class, on the other side, are signal expressions of this perception of both personhood and texts. Against this perception, literature is both menacing and attractive. A fragment by Cato attributed to the so-called ad Filium could not make this point more conspicuously: ${ }^{21}$

Dicam de istis Graecis suo loco, Marce fili, quid Athenis exquisitum habeam, et quod bonum sit illorum litteras inspicere, non perdiscere. Vincam nequissimum et

19 On census taking and the writing involved, see, generally, Nicolet 1980.48-88, Lemosse 1949.177, and Gargola 1995.76-77. On the marked aspect of writing on tabulae, see Meyer 2004.91-92; on ritualized forms of reading, see Valette-Cagnac 1997.

20 I am here drawing on the typological distinction between "meaning cultures" and "presence cultures" outlined by Gumbrecht 2004.78-86.

21 Cato ad Filium 1 C\&Sbl = Pliny NH 29.14. 
indocile esse genus illorum. Et hoc puta vatem dixisse: quandoque ista gens suas litteras dabit, omnia conrumpet, tum etiam magis, si medicos suos huc mittet. Iurarunt inter se barbaros necare omnis medicina, sed hoc ipsum mercede faciunt ut fides iis sit et facile disperdant. Nos quoque dictitant barbaros et spurcius nos quam alios Opicon appellatione foedant. Interdixi de medicis.

I shall speak about those Greeks in the proper place, Marcus my son, as to what I found out in Athens and what benefit there is in looking into their writings - not in learning them thoroughly. I will demonstrate that their race is most despicable and intractable. You should reckon what follows as pronounced by a vates: whenever this race will give its literature, it will corrupt everything; all the more so, if they will send their doctors here. They have taken an oath among themselves to kill all the barbarians by their medicine, but they do this very thing for a fee, so that they may be trusted and destroy easily. They also speak of us all the time as barbarians, and they insult us more filthily than others by calling us Opici. I have forbidden you to deal with doctors.

This fragment opens by featuring Cato's "speaking I" addressing his son and promising him that he would deal with the Greeks on another occasion. Through this deferral, Cato situates the Greeks in an Athens construed as peripheral that he has self-confidently examined and represents their writings as objects that are both alien and alienable. ${ }^{22}$ The alienable features that Cato attaches to Greek literature are here made prominent in his use of dare (to give). Produced by a despicable and fickle race, these writings - he warns his son-may be inspected (inspicere), but should not be learned thoroughly (perdiscere). Moreover, Cato predicts that Greek literature holds the potential to undo (conrumpere) everything and equates his pronouncement with that of a vates. As a figure of pre-poetic Roman song

22 See Dench 2005.324-26 and Dupont 2005. The question of ownership of Greek literature comes vividly into play in Horace Ars 128-35, where Greek literary texts are defined as communis (128) and publica materies (131). Through poetic manipulation and translation, these become an area of ius privatus (131). 
rejected at this time by Ennius, the vates becomes in this context a prop that empowers Cato's self-positioning. ${ }^{23}$ In what follows, Cato abruptly shifts his focus from literature to medicine and characterizes Greek doctors as conspirators and assassins operating under the guise of paid professionals. The language of destruction (necare, disperdere) that he uses at this point recalls the ruinous power (conrumpere) previously attributed to Greek literature. In turn, the echo suggests that Cato's distinction between inspicere and perdiscere does not rest simply on a different degree of attention paid to texts but also (and more poignantly) on the extent to which what is read penetrates the mind and molds both body and actions.

Like Leonardo and Horace, Cato acknowledges here the captivating power of the hyperreal; as opposed to them, he tries to contain it. Although poetry does not feature in this fragment, it is interesting to see that in marginalizing Greek literature both ethnically and geographically, Cato marginalizes the sources from which the early Latin poets drew material in order to create their craft. Cato resists the power of the hyperreal by adopting a whole series of binaries. These include Greek vs. Roman, himself vs. his son, literature vs. carmen, elite vs. professional, we vs. them, killing vs. generating, and so on. We may, indeed, choose to ignore these binaries and continue to represent Cato's views as backwards and unsophisticated; however, by giving some serious thought to what Cato says: poetry presupposes a mental intake that is bodily as well, we open up ourselves to the possibility of reading Roman poetry against its grain. Certainly, once we move our attention away from textual allusions as such and start taking the body factor into full account, we run the risk of writing very different literary histories and even understanding why the Romans did without literature for so long. The more binaries and associations we identify compressed in a text, the more are we in a position to acknowledge the perceptual frameworks that are at work in any given text. As readers, this means resisting the desire to transcend the materiality of our own realities and the hyperreality of the texts we read.

\section{University of Canterbury, Christchurch}

23 Cato's adoption of the vates as an authoritative prop counters the negative overtones that are made manifest in Livy's narrative of the Bacchanalian affair of 186 B.C.E. (39.8-18). This suggests changes in the social location of the vates and a tightening of control over religious practices. See also Gildenhard 2007.87-92, Wiseman 2006, Habinek 2005a.227-28, and Gruen 1990.34-78. 


\section{BIBLIOGRAPHY}

Austin, J. L. [1962] 1975. How to Do Things with Words. Oxford.

Barchiesi, A. 1997. "Otto punti su una mappa dei naufragi," in D. Fowler and S. Hinds, eds., Memoria, arte allusiva, intertestualità: Materiali e Discussioni 39.209-26.

Bredekamp, H. 2006. "One Step Beyond," in Tate etc. 6. http://www.tate. org.uk/tateetc/issue6/hyperrealism.htm 2010, "The Audience as Prisoner: Reflections on the Activity of the Object," http://video.ias.edu/audience-as-prisoner\#attachments

Bryson, N. 2003. “ The Neural Interface," in Blow-up: Photography, Cinema, and the Brain (essays by Warren Neidich, with an introduction by Norman Bryson). Riverside.

Butler, J. 1993. Bodies that Matter: On the Discursive Limits of "Sex." New York.

1997. Excitable Speech: A Politics of the Performance. New York.

Courtney, E. 1999. Archaic Latin Prose. Atlanta.

Cugusi, P., and M. T. Sblendorio Cugusi. 2001. Marco Porcio Catone Censore: Opere, 2 vols. Torino.

Dench, E. 1995. From Barbarians to New Men: Greek, Roman, and Modern Perceptions of Peoples of the Central Apennines. Oxford.

- 2005. Romulus's Asylum: Roman Identities from the Age of Alexander to the Age of Hadrian. Oxford.

de Saussure, F. 1916 [1959]. Course in General Linguistics (trans. W. Baskin). New York.

Dupont, F. 2005. "Altérité incluse," in F. Dupont and E. Valette-Cagnac, eds., Façons de parler grec à Rome. Paris. 255-77.

Edmunds, L. 2001. Intertextuality and the Reading of Roman Poetry. Baltimore.

Feeney, D., and J. T. Katz. 2006. "T. Habinek. The World of Roman Song: from Ritualized Speech to Social Order" (review) JRS 96.240-42.

Feeney, D. 2005. “The Beginnings of a Literature in Latin," JRS 95.226-40.

Foucault, M. 1972. Archaeology of Knowledge (trans. A. Sheridan). New York.

Gargola, D. J. 1995. Lands, Laws, and Gods: Magistrates and Ceremony in the Regulation of Public Lands in Republican Rome. Chapel Hill.

Gildenhard, I. 2007. Paideia Romana: Cicero's Tusculan Disputations (Cambridge Classical Journal, Proceedings of the Cambridge Philological Society, Suppl. 30). Cambridge. 
Goldberg, S. M. 2005. Constructing Literature in the Roman Republic: Poetry and Its Reception. Cambridge.

Gowers, E. 2009. "The Cor of Ennius," in W. Fitzgerald and E. Gowers, eds., Ennius Perennis: The Annals and Beyond (Cambridge Classical Journal Suppl. vol. 31). Cambridge.

Gruen, E. S. 1990. Studies in Greek Culture and Roman Policy. Berkeley.

Gumbrecht, H. U. 2004. Production of Presence: What Meaning Cannot Convey. Stanford.

Habinek, T. N. 1998. The Politics of Latin Literature: Writing, Identity, and Empire in Ancient Rome. Princeton.

2000. "Seneca's Renown: Gloria, Claritudo, and the Replication of the Roman Elite," ClassAnt 19.2.264-303.

- 2005a. The World of Roman Song: From Ritualized Speech to Social Order. Baltimore.

2005b. "Latin Literature between Text and Practice," TAPA 135.83-90.

Hall, J. 2009. Politeness and Politics in Cicero's Letters. Oxford.

Halpern, J. Y. 2003. Reasoning about Uncertainty. Cambridge, Mass.

Hinds, S. 1998. Allusion and Intertext: Dynamics of Appropriation in Roman Poetry. New York.

Jakobson, R. 1970. Essais de linguistique générale. Paris.

Lemosse, M. 1949. "L'affranchissement par le cens," RD 27.161-203.

Martindale, C. 1993. Redeeming the Text: Latin Poetry and the Hermeneutics of Reception. Cambridge. 2005. Latin Poetry and the Judgment of Taste. Oxford.

Mazzoli, G. 2004. "Riflessioni sulla semantica ciceroniana della gloria," in E. Narducci, ed., Cicerone tra antichi e moderni (Atti del IV Symposium Ciceronianum Arpinas, Arpino 9 maggio 2003). Firenze. 56-81.

Meyer, E. A. 2004. Legitimacy and Law in the Roman World: Tabulae in Roman Belief and Practice. Cambridge.

Mitchell, W. J. T. 2005. What Do Pictures Want? The Lives and Loves of Images. Chicago.

Neidich, W. 2006. "The Neurobiopolitics of Global Consciousness," Sarai Reader 2006: Turbulence. http://www.warrenneidich.com/ the-neurobiopolitics-of-global-consciousness/

Nicolet, C. 1980. The World of the Citizen in Republican Rome (trans. P. S. Falla). London. 
Norden, E. 1986. La prosa d'arte antica dal VI secolo a. C. all'età della Rinascenza (trans. B. Heinemann Campana). Roma (= LeipzigBerlin 19153).

Palmer, L. R. 1961³. . The Latin Language. London.

Sciarrino, E. 2011. Cato the Censor and the Beginnings of Latin Prose: From Poetic Translations to Elite Transcriptions. Columbus.

Stafford, B. M. (ed.) 2011. Bridging the Humanities-Neuroscience Divide: A Field Guide to a New Meta-Field. Chicago.

Steiner, D. T. 2002. Images in Mind in Archaic and Classical Greek Literature and Thought. Princeton.

Svenbro, J. 1993. Phrasikleia: An Anthropology of Reading in Ancient Greece. Ithaca, N.Y.

Timpanaro, S. 1988. "Alcuni tipi di sinonimi in asindeto in latino arcaico e loro sopravvivenze inlatina classico," RFIC 116.257-97, 385-428.

Valette-Cagnac, E. 1997. La lecture à Rome: rites et pratiques. Paris.

Virilio, P. 1994. The Vision Machine. Bloomington.

von Albrecht, M. 1989. Masters of Roman Prose from Cato to Apuleius: Interpretative Studies (trans. N. Adkin). Leeds.

Wang, Dale. 2013. The Body of a Poet: The Narratology of Ovid's Elegiac Subjectivity. Honours Thesis. University of Canterbury, Christchurch.

Winsbury, R. 2009. The Roman Book. London.

Wiseman, T. P. 2006. "Fauns, Prophets, and Ennius's Annales," Arethusa 39.513-30.

Zanker, G. 2004. Modes of Viewing in Hellenistic Poetry and Art. Madison.

Zanker, P. 1990. The Power of Images in the Age of Augustus (trans. A. Shapiro). Ann Arbor. 